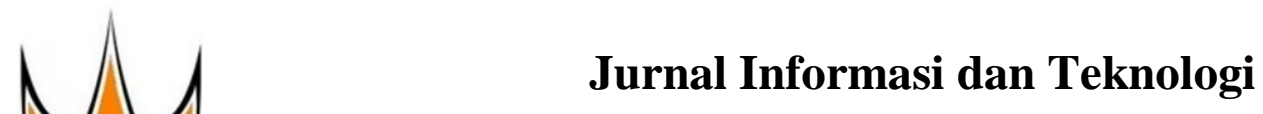

http://www.jidt.org

2021 Vol. 3 No. $2 \quad$ Hal: 72-77 ISSN: 2714-9730 (electronic)

\title{
Sistem Fuzzy Menggunakan Metode Sugeno dalam Akurasi Penentuan Suhu Kandang Ayam Pedaging
}

\author{
Darma Yunita Darmawi ${ }^{1 凶}$, Gunadi Widi Nurcahyo ${ }^{2}$, Sumijan $^{3}$ \\ ${ }^{1,2,3}$ Universitas Putra Indonesia YPTK Padang \\ darmayunita239@gmail.com
}

\begin{abstract}
Chicken meat is one of the most commonly consumed side dishes. To produce high quality chicken meat, a system is needed that makes it easy for breeders to buy chickens, one of which is the right system in determining the temperature of a broiler cage. The purpose of this study was to obtain a temperature appropriate to the age of the chickens as well as in its cultivation. In this case, the Fuzzy Sugeno method is used in an effort to build a systematic approach to generate the fuzzy rules from the input data sets given with fuzzy variables temperature, chicken age and decision. Where in each fuzzy variable there are linguistic variables, age (small, adolescent, and adult), temperature (cold, medium, and hot), decision (cold, ideal, hot). Later it will be processed with Matlab R2013a and can be implemented with Arduinno Mega 2560 using the Arduino IDE (Integrated Development Environment) programming compiler. A typical study in this study was conducted in a broiler cage with a size of approximately $40 \mathrm{X} 10 \mathrm{~m}$ with a capacity of about 5000 broilers. The result of testing for this method is the ideal temperature according to the age and temperature of the broiler house input. From the trials that have been carried out, it can be said that the Fuzzy Sugeno method which is implemented with the Arduino Mega 2560 microcontroller can increase the accuracy of the ideal temperature in broiler brackets.
\end{abstract}

Key words: Fuzzy, Sugeno, Arduino, Temperature, Chicken Coop.

\begin{abstract}
Abstrak
Daging ayam merupakan salah satu jenis lauk yang umum dikonsumsi. Rasa daging ayam yang enak dan ukurannya yang cukup besar, harganya yang murah menjadikan ayam makanan yang digemari oleh banyak orang. Untuk menghasilkan daging ayam berkualitas tinggi perlu sistem yang memudahkan peternak untuk memelihara ayam salah satunya yaitu sistem dalam akurasi penentuan suhu kandang ayam pedaging. Tujuan dari penelitian ini untuk mendapatkan suhu yang sesuai dengan umur ayam serta dalam pemiliharaan. Pada penelitian ini mengunakan metode Fuzzy sugeno dalam upaya untuk membangun pendekatan sistematis untuk membangkitkan aturan-aturan fuzzy dari himpunan data input-output yang diberikan Dengan variabel fuzzy suhu, umur ayam dan keputusan. dimana dalam setiap variabel fuzzy terdapat variabel linguistik, umur (kecil, remaja, dan dewasa), suhu (dingin, sedang, dan panas), keputusan (dingin, ideal, padanas) Nantinya akan di proses dengan Matlab R2013a dan dapat diimplemetasikan dengan Arduinno Mega 2560 menggunakan kompiler pemrograman Arduino IDE(Integrated Development Environment) Studi khasus dalam penelitian ini dilakukan pada kandang ayam pedaging dengan ukuran kurang lebih 40X10 m dengan kapasitas sekitas 5000 ekor ayam pedaging. Hasil dari pengujian terhadap metode ini adalah suhu ideal yang sesuai berdasarkan inputan umur dan suhu kandang ayam pedaging . dari uji coba yang telah dilakukan dapat disimpulkan Metode Fuzzy Sugeno yang di implementasikan dengan mikrokontroler Arduino Mega 2560 dapat meninggkat akurasi suhu ideal pada kandan ayam pedaging.
\end{abstract}

Kata kunci: Fuzzy, Sugeno, Arduino, Suhu, Kandang Ayam.

\section{Pendahuluan}

Peternakan merupakan subsektor pertanian yang memiliki peran penting dalam pemenuhan kebutuhan protein hewani yang semakin meningkat [1]. Seiring Khususnya untuk pertumbuhan ayam yang sangat baik meningkatnya jumlah penduduk dan tingkat pendapatan kandang terjadi perubahan suhu oleh karena itu masyarakat akan menyebabkan meningkatnya protein peran pemanas sangat penting untuk menjaga suhu hewan. Kemitraan merupakan strategi bisnis yang kandang tetap dalam zona nyaman ayam. Suhu yang dilakukan oleh dua pihak. Perusahaan sebagai inti dan dibutuhkan ayam pada kandang adalah $30^{\circ} \mathrm{C}-34^{\circ} \mathrm{C}$ [5]. peternak sebagai plasma yang selanjutnya dikenal Tingginya suhu lingkungan dapat mengakibatkan ayam dengan pola inti-plasma dengan prinsip saling mengalami stress di karenakan ayam tergolong dalam membutuhkan, saling menguntungkan dan saling hewan berdarah panas yang tidak mempunyai kelenjar menguatkan dengan tanggung jawab masing-masin [2]. keringat dan mengakibatkan ternak unggas dalam Salah satu sistem kemitraan usaha ternak ayam kondisi panas mengalami kesulitan dan bedampakk pedaging [3]. Daging ayam merupakan bahan pangan pada produktivitas dan bahkan berujung kematian. sumber protein hewan yang bergizi tinggi, lezat, mudah ditemui dan memiliki harga yang relatif murah [4].

Diterima: 16-09-2020 | Revisi: 07-01-2021 | Diterbitkan: 30-06-2021 |DOI: 10.37034/jidt.v3i2.95 
Peternak ayam pedaging sangat perlu menjaga kondisi dengan judul "Sistem Fuzzy Menggunakan Metode [6] kandang dan pemeliharaan ayam dengan baik untuk Sugeno dalam Akurasi Penentuan Suhu Kandang Ayam menghasilkan ayam dengan kualiatas yang baik pula. Pedaging”.

kandang yang cukup dengan kualitas baik dapat menghindari ayam yang dipelihara dari paparan beragam bibit penyakit, terutama bibit penyakit yang dapat ditularkan melalui udara [7]. Banyak peternak yang masih menggunakan cara manual untuk dalam memberi pakan dan menjaga suhu kandang ayam. Cara ini masih dirasa kurang efisien dan efektif.

Berdasarkan masalah di atas, untuk itu dilakukan proses perhitungan dan prediksi untuk dapat menghindari resiko kerugian pada peternak ayam. Salah satu metode yang di gunakan untuk melakukan proses penghitungan tersebut adalah metode fuzzy sugeno. Fuzzy merupakan suatu cara untuk memetakan suatu ruang input ke dalam suatu ruang output [8]. Kata-kata yang digunakan alam Fuzzy Logic memang tidak sepresiasi bilangan, namun kata-kata jauh lebih dekat dengan intuisi manusia [9]. Metode TakagiSugeno merupakan metode inferensi fuzzy untuk aturan yang direpresentasikan dalam bentuk (IF - THEN) dimana output sistem tidak berupa himpunan fuzzy, melainkan berupakonstanta atau persamaan linear [10]. Fungsi keanggotaan pada metode fuzzy Sugeno disebut fungsi singleton yaitu fungsi keanggotaan yang memiliki nilai keanggotaan 1 pada fungsi aktual tunggal dan 0 pada fungsi aktual yang lain. Proses defuzzifikasi pada metode Sugeno lebih efisien daripada metode mamdani. Hal ini dikarenakan metode fuzzy Sugeno menghitung fungsi output rule ke-i, akhir, dan output adalah sebuah weight average. Metode Sugeno untuk menetapkan alternatif terbaik dari sejumlah alternatif berdasarkan criteria tertentu [11]. Kelebihan dari logika fuzzy Sugeno adalah dengan orde nol seringkali sesuai untuk berbagai kebutuhan permodelan. Rule IF-THEN pada metode fuzzy Sugeno terdapat pada Persamaan [12].

Model Sugeno menggunakan fungsi keanggotaan Singleton, fungsi keanggotaan yang derajat keanggotaannya adalah 1 pada satu nilai segar dan 0 untuk nilai segar lainnya [13]. Suatu aturan fuzzy khas dalam model fuzzy Sugeno dibentuk: if $\mathrm{x}$ is $\mathrm{A}$ and $\mathrm{y}$ is $\mathrm{B}$ then $\mathrm{z}=\mathrm{f}(\mathrm{x}, \mathrm{y})$, dimana $\mathrm{A}$ dan $\mathrm{B}$ himpunan fuzzy dalam anteseden dan $\mathrm{z}=\mathrm{f}(\mathrm{x}, \mathrm{y})$ fungsi tegas dalam konsekuen. Jika $\mathrm{f}(\mathrm{x}, \mathrm{y})$ polimonial orde satu, FIS yang dihasilkan disebut model fuzzy Sugeno orde satu. Jika f konstan, dihasilkan model fuzzy Sugeno orde nol. Sistem inferensi fuzzy menggunakan metode Sugeno memiliki karakteristik, yaitu konsekuen tidak merupakan himpunan fuzzy, namun merupakan suatu persamaan linear dengan variabel-variabel sesuai dengan variabel- variabel inputnya [14].

Penelitian ini diharapkan dapat menigkatkan akurasi penentuan suhu ideal untuk pempermudah pemeliharaan ayam pedaging dan meningkat produktifitas ayam pedaging serta meminimalisir anggka kematian pada ayam pedaging. Berdasarkan uraian yang telah di jelaskan di atas, maka peneliti melakukan penelitian yang tuangkan dalam bentuk tesis

\section{Metodologi Penelitian}

Dalam metodologi penelitian ini dijelaskan beberapa tahapan yang akan dilakukan untuk dapat mengatasi permasalahan yang ada. Tahapan ini merupakan gambaran penelitian secara terstrukturdari penelitian yang akan dilakukan. Kerangka kerja penelitian disajikan pada Gambar 1. Kerangka kerja penelitian ini merupakan langkah-langkah yang dilakukan dalam penyelesaian masalah yang dibahas.

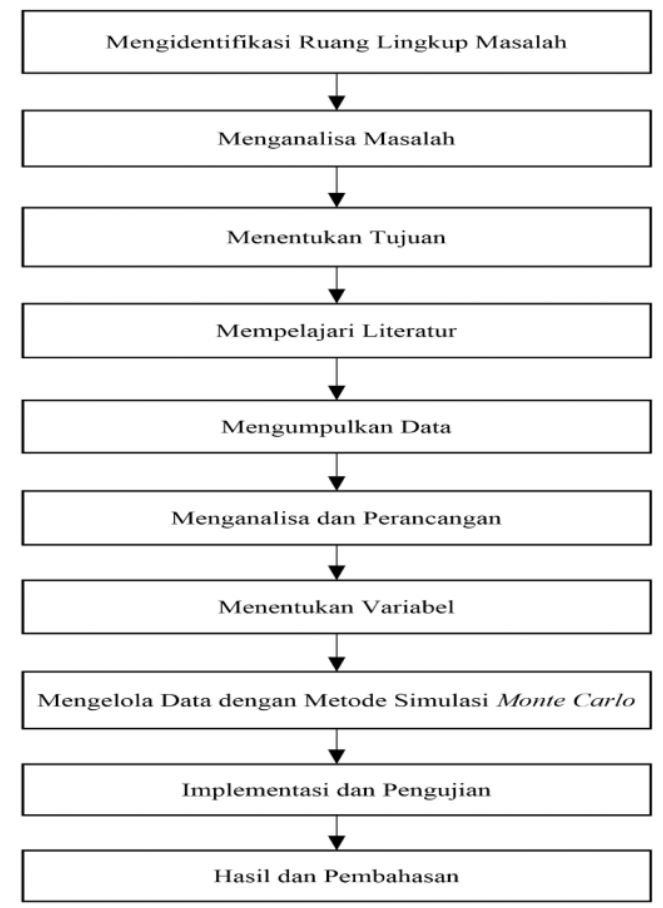

Gambar 1 Kerangka Kerja Penelitian

Uraian secara rinci terhadap masing-masing kerangka kerja yang telah disusun agar penelitian yang dilakukan dapat terlaksana secara terstruktur dan jelas.

\subsection{Mengidentifikasi Ruang Lingkup Masalah}

Tahap ini merupakan tahap awal untuk menentukan rumusan masalah yang terjadi pada suhu kandang ayam yaitu penerapan metode Fuzzy Sugeno dalam menghitung suhu yang ideal untuk ayam pada kandang ayam.

\subsection{Menganalisa Masalah}

Langkah analisis masalah adalah untuk dapat memahami masalah yang telah ditentukan ruang lingkup atau batasannya. Dengan menganalisa masalah yang telah ditentukan tersebut, maka diharapkan masalah dapat dipahami dengan baik.

\subsection{Menentukan Tujuan}

Tujuan penelitian adalah suatu hal yang akan dicapai dalam suatu penelitian yang dilakukan. Tujuan penelitian merupakan hasil akhir ideal yang diharapkan tercapai setelah penelitian tersebut dilakukan dan 
Menentukan tujuan penelitian sangat diperlukan agar 2.10 Pengujian

penelitian yang dilakukan bermanfaat bagi penggunanya.

Pada proses ini akan uji coba untuk menilai apakah

\subsection{Mempelajari Literatur}

Dipelajari beberapa literatur-literatur yang diperkirakan dapat digunakan. Kemudian literatur-literatur yang dipelajari tersebut di seleksi dan dipilih teratur mana yang akan digunakan dalam penelitian. Literatur diambil dari berbagai sumber yaitu berupa artikel, jurnal ilmiah tentang metode Fuzzy Sugeno, serta bahan bacaan lain yang mendukung.

\subsection{Mengumpulkan data}

Mengumpulkan data dilakukan untuk mengumpulkan semua data-data yang diperlukan. Teknik yang dilakukan dalam mengumpulkan data dalam penelitian ini dengan cara wawancara dan observasi . Teknik wawancara adalah untuk mengetahui suhu kandang dan umur ayam dalam beberapa fase. Teknik observasi adalah teknik pengamatan lansung kelapangan dengan mencatat data-data yang di perlukan . Data tersebut diolah dengan Matlab mengunakan Metode Sugeno yang menentukan variabel pada suhu ruangan dan pupulasi pada ayam.

\subsection{Menganalisa}

Pada tahap ini akan dilakukan analisa terhadap permasalah yang ada berdasarkan data-data yang telah dikumpulkan dengan tahapan-tahapan yang ada dalam metode Fuzzy Sugeno.

\subsection{Perancangan}

Setelah melakukan analisa, selanjutnya akan dilakukan perancangan pada sistem yang akan diterapkan, dalam tahap ini akan dibentuk sketsa berupa data flow diagram yang mengambarkan alur proses input dan output dari sistem.

\subsection{Menentukan Variabel}

Sebelum data diolah, terlebih dahulu ditentukan dengan menggunakan variable input dan output. Dalam metode Fuzzy sugeno mengunakan tiga variabel yaitu variable suhu, variabel ayam dan variabel keputusan. Masing-masing variabel memiliki 3 himpunan yaitu pada variabel suhu terdiri dari suhu dingin, sedang, panas. Variabel ayam terdiri dari kecil, remaja, dewasa. Dan variabel keputusan terdiri dari suhu dingin, panas dan ideal.

\subsection{Implementasi Dengan Metode Fuzzy Sugeno}

Setelah menentukan variabel yang ada, selanjutnya akan dilakukan pengolahan terhadap data yang diperoleh dari pengamatan. Langkah-langkah yang dilakukan dalam pengolahan data adalah:
a. Pembentukan Fuzzy;
b. Komposisi Aturan Fuzzy (IF ...THEN);
c. Penegasan (Defuzzifikasi). sistem sudah berjalan sesuai dengan yang diharapkan pada sistem, serta untuk mengetahui jika ada kemungkinan lain yang dapat dilakukan untuk pengembangan sistem.

\subsection{Hasil}

Pada tahap ini akan diuraikan hasil dari pengolahan dan pengujian data yang telah dilakukan dengan menggunakan metode simulasi Fuzzy Sugeno. Hasil dari perhitungan tersebut akan dibandingkan dengan data-data nyata yang ada untuk melihat tingkat persentase $(\%)$ keakuratannya.

\section{Hasil dan Pembahasan}

Data yang dibutuhkan adalah data suhu, umur ayam dan keputusan. Dalam melakukan pengumpulkan data perlu dilakukan observasi yaitu pengamatan secara langsung ditempat penelitian serta wawancara dengan narasumber. Variabel suhu dan umur ayam sebagai input dalam sistem fuzzy. Sedangkan variabel Keputusan sebagai output dengan menentukan keadaan pada suhu. Berikut adalah algoritma dalam proses perhitungan menggunakan metode Fuzzy Sugeno:

\subsection{Tahap Pembentukan Fuzzy (Fuzzifikasi)}

Pada tahap pembentukan fuzzifikasi untuk menghitung himpunan fuzzy dari variabel suhu dan umur ayam dalam menentukan derajat keanggotaan dimana nilainilai tersebut menjadi anggota dari himupunan fuzzy. Variabel yang dapat digunakan adalah variabel suhu , variabel umur ayam dan variabel keputusan . Masingmasing variabel dapat dibagi menjadi tiga himpunan. Pada variabel suhu terdiri dari himpunan fuzzy dingin, sedang dan panas. Pada variabel umur ayam terdiri dari himpunan fuzzy kecil , remaja dan dewasa. Pada variabel keputusan terdiri dari himpunan fuzzy terlalu panas, terlalu dingin dan ideal. Standar temperatur disajikan pada Tabel 1.

Tabel 1 Pembagian Himpunan Fuzzy

\begin{tabular}{|c|c|c|c|}
\hline Fungsi & $\begin{array}{l}\text { Nama } \\
\text { Variabel }\end{array}$ & $\begin{array}{l}\text { Keanggotaan } \\
\text { Fuzzy }\end{array}$ & $\begin{array}{l}\text { Domaian/ } \\
\text { parameter }\end{array}$ \\
\hline \multirow{6}{*}{ Input } & \multirow{3}{*}{ Suhu } & Dingin & $26-30$ \\
\hline & & Sedang & $29-31$ \\
\hline & & Panas & $31-34$ \\
\hline & \multirow{3}{*}{$\begin{array}{l}\text { Umur } \\
\text { Ayam }\end{array}$} & Kecil & $1-14$ \\
\hline & & Remaja & $13-28$ \\
\hline & & Dewasa & $27-35$ \\
\hline \multirow{3}{*}{ Output } & \multirow{3}{*}{ Keputusan } & Dingin & $<25$ \\
\hline & & Panas & $>35$ \\
\hline & & Ideal & $=30$ \\
\hline $\begin{array}{l}\text { ntuk } \\
\text { enguna } \\
\text { rsamaa }\end{array}$ & $\begin{array}{l}\text { nentukan } \\
\text { 1). }\end{array}$ & $\begin{array}{l}\text { nilai pada } \\
\text { segitiga de }\end{array}$ & $\begin{array}{l}\text { mpunan } \\
\text { rumus }\end{array}$ \\
\hline
\end{tabular}

$\mu[x]=\left\{\begin{array}{lc}0 ; \quad x \leq \text { aatau } x \geq c \\ \frac{x-a}{b-a} ; & a \leq x \leq b \\ \frac{b-x}{c-b} ; & b \geq x \geq c\end{array}\right.$ 
Berikut ini fungsi menentukan nilai himpunan Fuzzy menghasikan perintah "then". Aturan dasar fuzzy yang dengan ke anggotaan nya. di gunakan untuk menentukan kondisi suhu pada

a. Suhu kandang ayam dapat dilihat pada Tabel 2.

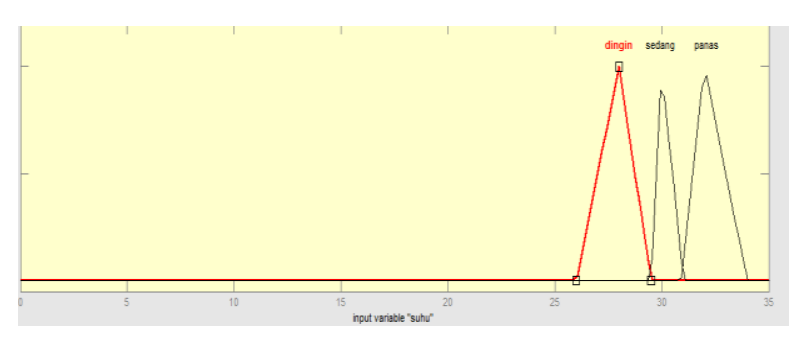

Gambar 2. Fungsi Keanggotaan Umur Ayam

Tabel 2 Inferensi Fuzzy

\begin{tabular}{|c|c|c|c|c|c|c|}
\hline Rule & & Suhu & & Umur & & Keputusan \\
\hline [R1] & If & Dingin & And & Kecil & Then & Dingin \\
\hline [R2] & If & Sedang & And & Kecil & Then & Dingin \\
\hline [R3] & If & Panas & And & Kecil & Then & Ideal \\
\hline [R4] & If & Dingin & And & Remaja & Then & Dingin \\
\hline [R5] & If & Sedang & And & Remaja & Then & Ideal \\
\hline [R6] & If & Panas & And & Remaja & Then & Panas \\
\hline [R7] & If & Dingin & And & Dewasa & Then & Ideal \\
\hline [R8] & If & Sedang & And & Dewasa & Then & Panas \\
\hline [R9] & If & Panas & And & Dewasa & Then & Panas \\
\hline
\end{tabular}

Gambar 2 menunjukan fungsi keanggotaan himpunan 3.3 Fuzzy dingin, sedang, dan panas dari variabel suhu. Untuk nilai $\mu$ Dingin dengan ketentuan.

$$
\left\{\begin{array}{cc}
1 & x \leq 26 \\
\frac{x-26}{28-26} & 26 \leq x \leq 28 \\
\frac{30-x}{30-26} & 28 \geq x \geq 30
\end{array}\right.
$$

Untuk nilai $\mu$ Sedang dengan ketentuan.

$$
\left\{\begin{array}{cc}
0 & x \leq 29 \\
\frac{x-29}{30-29} & 29 \leq x \leq 30 \\
\frac{31-x}{31-30} & 30 \geq x \geq 31
\end{array}\right.
$$

Untuk nilai $\mu$ Panas dengan ketentuan.

$$
\left\{\begin{array}{cc}
0 & x \leq 31 \\
\frac{x-31}{32,531} & 31 \leq x \leq 32,5 \\
\frac{34-x}{34-32,5} & 32,5 \geq x \geq 34
\end{array}\right.
$$

b. Umur ayam

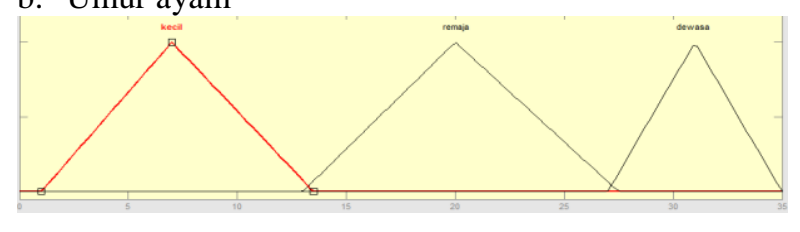

Gambar 3. Fungsi Keanggotaan Umur Ayam

Fungsi keanggotaan himpunan Fuzzy kecil, remaja dan dewasa dari variabel Umur Ayam.

Untuk nilai $\mu$ Kecil dengan ketentuan.

$$
\left\{\begin{array}{cc}
1 & x \leq 1 \\
\frac{x-1}{7-1} & 1 \leq x \leq 7 \\
\frac{14-x}{14-7} & 7 \geq x \geq 14
\end{array}\right.
$$

Untuk nilai $\mu$ Remaja dengan ketentuan.

$$
\left\{\begin{array}{cc}
0 & x \leq 13 \\
\frac{x-13}{20-13} & 13 \leq x \leq 20 \\
\frac{28-x}{28-20} & 20 \geq x \geq 28
\end{array}\right.
$$

Untuk nilai $\mu$ Dewasa dengan ketentuan.

$$
\left\{\begin{array}{cc}
0 & x \leq 27 \\
\frac{x-27}{31-27} & 27 \leq x \leq 31 \\
\frac{35-x}{35-31} & 31 \geq x \geq 35
\end{array}\right.
$$

\subsection{Tahap Inferensi Fuzzy (IF...THEN)}

Pada aturan fuzzy ini akan memberikan aturan-aturan dalam fuzzy sistem yang akan dibuat dengan $\mu$ dingin $[26]=\frac{26-25}{27-25}=\frac{1}{2}=0,5$ menggunakan perintah "if" dan "and" dan

Tahapan dimana besaran fuzzy hasil dari sistem inferensi, diubah menjadi besaran tegas. Input dari defuzzifikasi adalah suatu himpunan yang diperoleh dari inferensi fuzzy, sedangkan output yang dihasilkan merupakan bilangan pada domain himpunan fuzzy. Berikut ini hitungan untuk menentukan nilai fuzzy yang berdasarkan rule pada tabel Inferensi Fuzzy. Dapat menggunakan rumus:

$$
Z \sum \frac{\mu i Z i}{\mu i}
$$

\section{Dimana:}

- $\quad Z=$ output perhitungan logika fuzzy

- $\mathrm{Zi}=\mathrm{Z}$ masing-masing rule

- $\mu \mathrm{i}=$ derajat keanggotaan hasil proses.

[R1] Jika suhu dingin[29] dan umur kecil [5] maka keputusan dingin

$\mu$ dingin $[29]=\frac{29-29}{29-30}=\frac{0}{1}=0$

$\mu$ kecil $[5]=\frac{5-1}{7-1}=\frac{4}{6}=0,66$

Dingin $\cap$ kecil $=0,66$

$Z \frac{0,66(25)+0(30)}{0,66+0}=\frac{16,5}{0,66}=25$ (dingin)

[R2] Jika suhu sedang [30] dan umur kecil [5] maka keputusan dingin

$\mu$ sedang $[30]=\frac{30-29}{30-29}=\frac{1}{1}=1$

$\mu$ kecil [5] $=\frac{5-1}{7-1}=\frac{4}{6}=0,66$

Sedang $\cap$ kecil $=0,66$

$z \frac{0,66(25)}{0,66}=\frac{16,5}{0,66}=25$ (dingin)

[R3] Jika suhu panas [32] dan umur kecil [5] makan keputusan ideal

$$
\begin{aligned}
& \mu \text { panas }[32]=\frac{32-31}{32-31}=\frac{1}{1}=1 \\
& \mu \text { kecil }[5]=\frac{5-1}{7-1}=\frac{4}{6}=0,66 \\
& \text { Panas } \cap \text { kecil }=0,66 \\
& Z \frac{0,66(30)}{0,66}=\frac{19,8}{0,66}=30 \text { (ideal) }
\end{aligned}
$$

[R4] Jika suhu dingin [26] dan umur remaja [17] maka keputusan dingin 
$\mu$ remaja $[17]=\frac{17-13}{20,5-13}=\frac{4}{7,5}=0,53$
Dingin $\cap$ remaja $=0,5$

$z \frac{0,5(25)}{0,5}=\frac{12,5}{0,5}=25$ (dingin)

[R5] Jika suhu sedang [29] dan umur remaja [17] maka keputusan ideal

$$
\begin{aligned}
& \mu \text { sedang }[29]=\frac{29-29}{30-29}=\frac{0}{1}=0 \\
& \mu \text { remaja }[17]=\frac{17-13}{20,5-13}=\frac{4}{7,5}=0,53 \\
& \text { Sedang } \cap \text { remaja }=0,5 \\
& Z \frac{0,53(30)}{0,53}=\frac{15,9}{0,53}=30 \text { (ideal) }
\end{aligned}
$$

[R6] Jika suhu panas [33] dan umur remaja [17] maka keputusan panas

$$
\begin{aligned}
& \mu \text { panas }[33]=\frac{34-33}{34-30}=\frac{1}{4}=0,25 \\
& \mu \text { remaja }[17]=\frac{17-13}{20,5-13}=\frac{4}{7,5}=0,53 \\
& \text { Sedang } \cap \text { remaja }=0,25 \\
& Z \frac{0,25(35)}{0,25}=\frac{8,75}{0,25}=35 \text { (panas) }
\end{aligned}
$$

[R7] Jika suhu dingin [26] dan umur dewasa [32] maka keputusan ideal

$$
\begin{aligned}
& \mu \text { dingin }[26]=\frac{26-25}{27-25}=\frac{1}{2}=0,5 \\
& \mu \text { dewasa }[32]=\frac{35-32}{35-27}=\frac{3}{8}=0,37 \\
& \text { Sedang } \cap \text { dewasa }=0,37 \\
& Z \frac{0,37(30)}{0,37}=\frac{11,1}{0,37}=30 \text { (ideal) }
\end{aligned}
$$

\begin{tabular}{|c|c|c|c|c|c|}
\hline Ayam & Rule & Suhu & Umur & $\begin{array}{l}\text { Nilai } \\
\text { Fuzzy }\end{array}$ & Keputusan \\
\hline 1. & [R1] & Dingin & Kecil & 25 & Dingin \\
\hline 2. & [R2] & Sedang & Kecil & 25 & Dingin \\
\hline 3. & [R3] & Panas & Kecil & 30 & Ideal \\
\hline 4. & [R4] & Dingin & Remaja & 25 & Dingin \\
\hline 5. & [R5] & Sedang & Remaja & 30 & Ideal \\
\hline 6. & [R6] & Panas & Remaja & 35 & Panas \\
\hline 7. & [R7] & Dingin & Dewasa & 30 & Ideal \\
\hline 8. & [R8] & Sedang & Dewasa & 35 & Panas \\
\hline 9. & [R9] & Panas & Dewasa & 35 & Panas \\
\hline
\end{tabular}

[R8] Jika suhu sedang [30] dan umur dewasa [32] keputusan panas

$$
\begin{aligned}
& \mu \text { sedang }[30]=\frac{31-30}{30-29}=\frac{1}{2}=0,5 \\
& \mu \text { dewasa }[32]=\frac{35-32}{35-27}=\frac{3}{8}=0,37 \\
& \text { Sedang } \cap \text { dewasa }=0,37 \\
& Z \frac{0,37(35)}{0,37}=\frac{12,95}{0,37}=35 \text { (panas) }
\end{aligned}
$$

[R9] Jika suhu panas [33] dan umur dewasa [32] maka keputusan panas

$$
\begin{aligned}
& \mu \text { panas [33] }=\frac{34-33}{34-30}=\frac{1}{4}=0,25 \\
& \mu \text { dewasa }[32]=\frac{35-32}{35-27}=\frac{3}{8}=0,37 \\
& \text { Panas } \cap \text { dewasa }=0,25 \\
& z \frac{0,25(35)}{0,25}=\frac{8,75}{0,25}=35 \text { (panas) }
\end{aligned}
$$

Tabel 3 Hasi Nilai Fuzzy

Pada tabel di atas ini dapat dilihat hasil pengujian atau nilai Fuzzy serta keputusan dari beberapa percobaan yang diujiakan secara manual dan juga diujikan menggunakan aplikasi Matlab.

\subsection{Perancangan fisik alat}

Merupakan tahap awal dalam proses pemasangan pada hardware dan analisa permasalahan dari sistem alat yang akan dibuat. Rancangan fisik alat dapat dilihat pada Gambar 4.

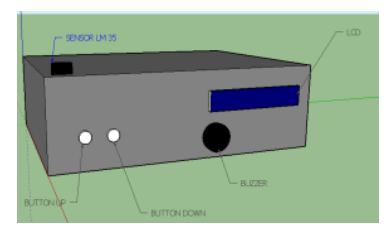

Gambar 4. Rancangan Fisik Alat

Dari rancangan fisik alat terdapat juga rangakaian sistem dari bangunan alat yaitu sensor suhu, buzzer, lcd, arduino mega2560, sensor $\operatorname{lm} 35$ dapat dilihat pada Gambar 5.

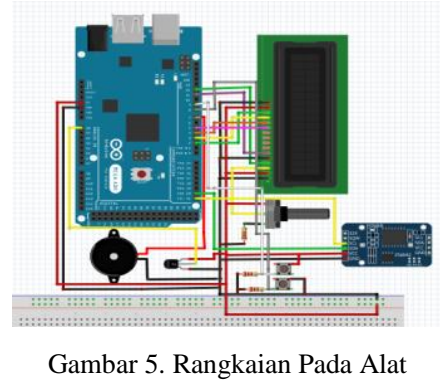

Berikut ini keterangan dari beberapa komponen yang di gunakan pada alat suhu kandang ayam pedaging, yaitu:

a.Arduino mega 2560 merupakan salah satu dari macam mikrokontroller sangat kompatible dengan bahasa pemrograman $\mathrm{C}$ maupun $\mathrm{C}++$. Di gunakan sebagai pusat pemrosesan data dan pengendalian data.

b.LCD (Liquid Crystal Display) merupakan suatu media penampilan data yang sangat efektif dan efisien. Nodul LCD berukuran 16 karakter x 2 baris. Di gunakan untuk menapilkan informasi suhu, umur, dan status keputusan.

c. Rtc (Real Time Clock) merupakan sebuah modul yang dapat menampilkan waktu dan tanggal secara real time atau sesuai dengan waktu nyata di thgunakan untuk menghitung umur ayam secara otomatis.

d.Sensor $\operatorname{lm} 35$ adalah komponen elektronika yang memiliki fungsi untuk mengubah besaran suhu menjadi besaran listrik dalam bentuk tegangan di gunakan untuk membaca suhu pada kandang ayam pedaging. 
e.Buzzer adalah sebuah komponen elektronika yang berfungsi untuk mengubah getaran listrik menjadi getaran suara di gunakan sebagai alaram peringatan apabila suhu tidak ideal.

f. Button adalah perangkat/saklar sederhana yang berfungsi untuk menghubungkan atau memutuskan aliran arus listrik dengan sistem kerja tekan unlock (tidak mengunci) digunakan untuk menhitung umur ayam secara menual.

\section{Kesimpulan}

MetodeFuzzy Sugeno telah berhasil diterapkan untuk meningkatkan akurasi penentuan suhu kandang ayam pedaging berdasarkan data yang di dapat dari hasil wawancara dengan peternak. telah berhasil diuji dengan menggunakan aplikasi Matlab versi R2013a dan diimplementasikan mengunakan mikrokontroller Arduino Mega 2560 dan menunjukkan tingkat akurasi perbandingan antara hasil simulasi dengan data real yaitu $90 \%$.

\section{Daftar Rujukan}

[1] Syam, R. F., Soepranianondo, K., Lokapirnasari, W. P., Soeharsono, S., Hidanah, S., \& Ardianto, A. (2019). Analisis Usaha Pemberian Bakteri Asam Laktat (BAL) pada Ayam Pedaging terhadap Persentase Berat Karkas. Jurnal Sain Peternakan Indonesia, 14(4), 338-344. DOI https://doi.org/10.31186/jspi.id.14.4.338-344 .

[2] Kurnianto, A., Subekti, E., \& Nurjayanti, E. D. (2018). Analisis Usaha Peternakan Ayam Broiler Pola Kemitraan Inti-Plasma (Studi Kasus Peternak Plasma PT. Bilabong di Kecamatan Limpung Kabupaten Batang). Mediagro, 14(2). DOI: http://doi.org/10.31942/md.v14i2.2747 .

[3] Amam, A., Fanani, Z., Hartono, B., \& Nugroho, B. A. (2019). Usaha Ternak Ayam Pedaging Sistem Kemitraan Pola Dagang Umum: Pemetaan Sumber Daya dan Model Pengembangan. Sains Peternakan: Jurnal Penelitian Ilmu Peternakan, 17(2)

https://doi.org/10.20961/sainspet.v17i2.26892 .

[4] Rini, S. R., Sugiharto, S., \& Mahfudz, L. D. (2019). Pengaruh Perbedaan Suhu Pemeliharaan terhadap Kualitas Fisik Daging Ayam Broiler Periode Finisher. Jurnal Sain Peternakan Indonesia, 14(4), 387-395. https://doi.org/10.31186/jspi.id.14.4.387-395 .

[5] Mansyur, M. F. (2018). Rancangan Bangun Sistem Kontrol Otomatis Pengatur Suhu dan Kelembapan Kandang Ayam Broiler Menggunanakan Arduino. Journal of Computer and
Information System (J-CIS), I(1), 28-39. DOI: https://doi.org/10.31605/jcis.v1i1.228.

[6] Puspasari, F., Fahrurrozi, I., Satya, T. P., Setyawan, G., \& Al Fauzan, M. R. (2018). Prototipe Sistem Kendali Suhu dan Kelembaban Kandang Ayam Broiler Melalui Blynk Server Berbasis Android. Wahana Fisika Jurnal Fisika dan Terapannya, 3(2), 143-147. DOI: https://doi.org/10.17509/wafi.v3i2.14060 .

[7] Sadarman, S., Wahyuni, A. E. T. H., Tabbu, C. R., \& Budhiarta, S. (2011). Hubungan Antara Praktek Manajemen Pemeliharaan dengan Kejadian Avian Influenza pada Peternakan Ayam Pedaging di sektor 3 Milik Mitra PT. Duta Technovet di DIY Selama Satu Siklus Pemeliharaan. Jurnal Peternakan, 8(1).

[8] Saputri, A. D., Ramadhani, R. D., \& Adhitama, R. (2019). Logika Fuzzy Sugeno untuk Pengambilan Keputusan dalam Penjadwalan dan Pengingat Service Sepeda Motor. Journal of Informatics, Information System, Software Engineering and Applications (INISTA), 2(1), 49-55. DOI:https://doi.org/10.20895/inista.v2i1.95

[9] Maulana, A., \& Rizki, S. N. (2018). Sistem Pengambilan Keputusan dalam Penerimaan Proyek Pembuatan Kapal Menggunakan Metode Fuzzy. Simetris: Jurnal Teknik Industri, Mesin, Elektro dan Ilmu Komputer, 9(2), 723-730. DOI: https://doi.org/10.24176/simet.v9i2.2110 .

[10]Mukaromah, M. (2019). Penerapan Metode Fuzzy Sugeno untuk Menentukan Jalur Terbaik Menuju Lokasi Wisata di Surabaya. Jurnal Matematika Sains dan Teknologi (JMST), 20(2). DOI: https://doi.org/10.33830/jmst.v20i2.187.2019 .

[11]Putri, A. D. (2016). Fuzzy Logic untuk Menentukan Lokasi Kios Terbaik di Kepri Mall dengan Menggunakan Metode Sugeno. Jurnal Edik Informatika, 3(1), 49-59.

[12] Oktavia, C. A., \& Maulidi, R. (2019). Penerapan Logika Fuzzy Sugeno untuk Penentuan Reward Pada Game Edukasi Aku Bisa. Juti: Jurnal Ilmiah Teknologi Informasi,17(2). DOI: http://dx.doi.org/10.12962/j24068535.v17i2.a825 .

[13] Alfita, R., Mamluah, D., Ulum, M., \& Nahari, R. V. (2017). Implementation of Fuzzy Sugeno Method for Power Efficiency. International Journal of Advanced Engineering Research and Science, 4(9). DOI: https://dx.doi.org/10.22161/ijaers.4.9.1 .

[14]Sitio, S. L. M. (2018). Penerapan Fuzzy Inference System Sugeno untuk Menentukan Jumlah Pembelian Obat (Studi Kasus: Garuda Sentra Medika). Jurnal Informatika Universitas Pamulang, 3(2), 104-109. DOI: http://dx.doi.org/10.32493/informatika.v3i2.1522 . 